\title{
Перспективы генерации терагерцового излучения в нелинейных кристаллах семейства боратов
}

\author{
Н.А. Николаев ${ }^{1}$, А.А. Мамрашев ${ }^{1, *}$, В.Д. Анцыгин ${ }^{1}$, \\ Г.В. Ланский ${ }^{2}$ Ю.М. Андреев \\ ${ }^{1}$ Институт автоматики и электрометрии СО РАН \\ ${ }^{2}$ Институт мониторинга климатических и экологических систем СО РАН \\ ${ }^{3}$ Томский государственный университет \\ *E-mail: mamrashev@iae.nsk.su
}

DOI: 10.31868/RFL2020.120

Кристаллы семейства боратов нашли широкое применение в различных областях нелинейной оптики благодаря их преимуществам: относительно большому эффективному нелинейному коэффициенту, широкому спектральному диапазону прозрачности, высокому порогу разрушения и т. д. [1]. К типичным представителям кристаллов этого семейства относятся бета-борат бария ( $\beta$ $\left.\mathrm{BaB}_{2} \mathrm{O}_{4}, \mathrm{BBO}\right)$, триборат лития $\left(\mathrm{LiB}_{3} \mathrm{O}_{5}, \mathrm{LBO}\right)$ и триборат висмута $\left(\mathrm{BiB}_{3} \mathrm{O}_{6}, \mathrm{BIBO}\right)$.

В последнее время исследователи начали проявлять интерес к применению этих материалов в терагерцовой (ТГц) области спектра. Измерены их терагерцовые оптические свойства - показатель преломления и коэффициент поглощения при комнатной температуре и температуре жидкого азота [2-4]. В работе рассмотрены перспективы нелинейного преобразования излучения волоконных лазеров (длины волн 1 мкм и 1,5 мкм) в терагерцовое за счет генерации разностных частот (ГРЧ). Наиболее перспективным представляется преобразование в излучение суб-ТГц (миллиметрового) диапазона благодаря большей длине когерентности и низкому поглощению на фононных модах. Этот диапазон актуален для телекоммуникационных систем нового поколения, в т. ч. 6G. B качестве примера на рис. 1 приведены расчётные кривые коллинеарного фазового согласования для процесса ГРЧ в кристалле ВВО и сравнение его коэффициента поглощения с другими боратами в ТГц области.
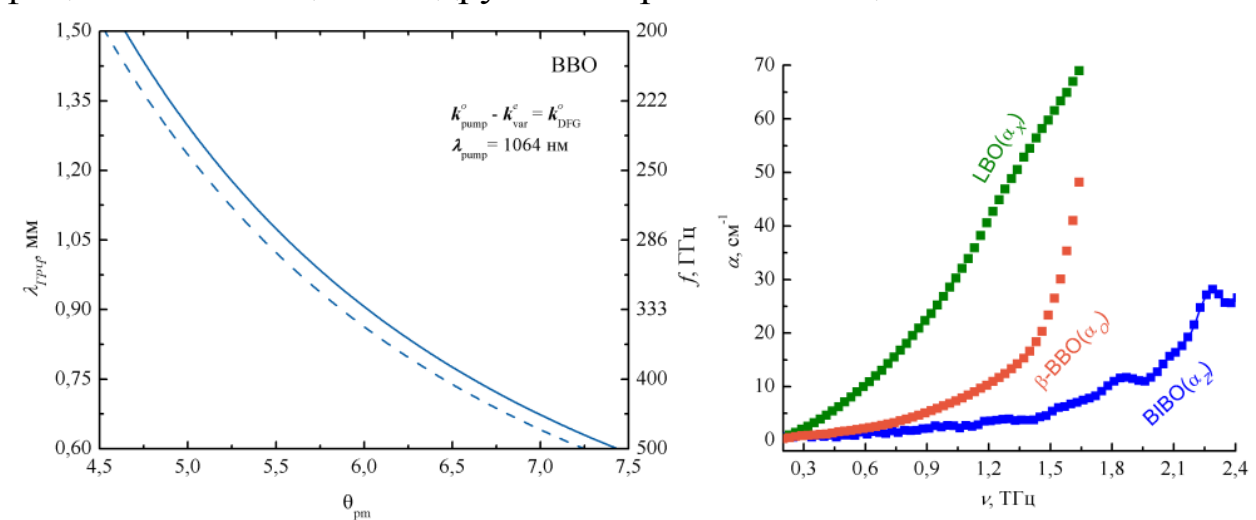

Рис. 1. Кривые фазового синхронизма ГРЧ в кристалле ВВО при накачке на длине волны 1,064 мкм при температуре 300 К (сплошная линия) и 77 К (пунктир), слева. Спектры поглощения кристаллов семейства боратов в ТГц спектральном диапазоне, справа.

\section{Литература}

[1] C. Chen, T. Sasaki et al. Nonlinear optical borate crystals, principles and applications, 1st ed., Wiley-VCH, 2012, $387 \mathrm{p}$.

[2] N. A. Nikolaev, Yu. M Andreev et al., Journal of Physics: Conference Series, 951, 012003 (2018)

[3] N. A. Nikolaev, Yu. M Andreev et al., Journal of Physics: Conference Series, 951, 012005 (2018)

[4] Y. Li, J. Huang et al., Results in Physics, 16, 102815 (2020) 